\title{
ORXX
}

Vol. XIII No. 1

April 1975

\section{Notes and News}

The award of the Getty Prize for outstanding achievement in conservation to our Peruvian Vice-President Felipe Benavides gives us immense pleasure and if ever an award was deserved this one was. Felipe Benavides exploded on the conservation scene not many years ago, has domi-

Prize to nated his Latin American corner ever since, and can be a credited with a major part in at least one successful rescue Whirlwind operation, that of the vicuña. Tireless, fearless, incredibly energetic, determined and at times ruthless, he launches himself from one trouble spot to another, castigating, encouraging, persuading, arguing, and all with such zest and enthusiasm that the most unlikely citadels capitulate. His logic is irrefutable and his ideas and plans always well thought out and practical. He is not so much a breath of fresh air as a whirlwind, and those of us who have been swept up in the gale can only hope that he has many more years to give to conservation battles.

'A grand example of conservation at its best', is how IUCN describes the plan for a world-wide system of biosphere reserves that is being drawn up under UNESCO's Man and the Biosphere Programme (MAB) to protect examples of all the world's biomes. These carefully chosen reserves A World which will supplement, and may sometimes incorporate, Plan existing national parks, will conserve (and sometimes for Reserves restore) the diversity and integrity of plant and animal communities in natural ecosystems, and provide areas for both ecological and environmental research, especially base line and educational studies. It is expected that about 200 areas will be selected to give a comprehensive cover. All reserves will have a sacrosanct 'core', surrounded by a protective buffer zone to which access and use will usually be restricted. One of the big hurdles that conservationists face is how to get across to the man in the street that wildlife and natural habitat bear any relation to everyday life. But at least there is now a growing and widespread realisation that earth's resources are not infinite, are being overexploited, and must therefore 
be properly managed. The biosphere reserves programme is designed to provide a scientific basis for management.

Yosemite National Park in the USA is usually instanced as the arch example of a park being destroyed by overuse. But Japan has even worse examples. The Fuji-Kakone-Izu National Park, covering 122,000 ha., which is only one

hour from Tokyo, now has over 72 million visitors a Japanese year; Seto-naikal $(65,000$ ha.) has 46 million, and JoshinParks Crushed etsu-Kogen $(188,000$ ha.) over 18 million. Only three by Visitors national parks record under one million visitors a year, and the total for the 23 national parks shot up from 140 million in 1960 to 300 million in 1970. In 1971 the daily number of visitors to Kakone was 150,000 . Dr Tetsumaro Senge, of Tokyo University, writing in the Rumanian Ocrotirea Naturii, urges the need for Japan to create more national parks or recreation areas near the big cities, remove all accommodation from inside the parks, control the number of visitors each day and replace private cars with buses. Otherwise, he says, 'the national parks will be crushed in the near future under the enormous mass of visitors'.

The Wild Creatures and Wild Plants Protection Bill, introduced into the House of Commons by Peter Hardy, MP, who won first place in the private members' ballot, has had its second reading at the time of going to press, and is confidently expected to finish the course. It is a conflaProtection tion of Lord Cranbrook's Wild Creatures Bill with the Bill Wild Plant Protection Bill which has been in preparation in Britain by the Coupcil for Nature and others for several years, and was recently adopted by Lord Beaumont. The Bill aims to fill in all the gaps in existing legislation, and provide a means by which any animal or plant which becomes rare can be protected by addition to a schedule by the appropriate Minister. At present there are three mammals (dormouse, greater horseshoe and mouse-eared bats), two reptiles (sand lizard, smooth snake), one amphibian (natterjack toad) and one butterfly (large blue) on the animal schedule, and 21 plants, including mezereon and four species of orchid, on the plant schedule.

The nene, or Hawaiian goose Branta sandvicensis, found only in Hawaii, is one of the few species that have been saved from near extinction by captive breeding and restored to the wild. But nobody knows how well it is doing. In 1949, when rescue operations began, with captive breedIs the ing in both Hawaii and England (by the Wildfowl Trust, Nene Really stimulated by Sir Peter Scott), there were under 50, and Saved? many of those were semi-domesticated. Since then 1300 captive-bred birds have been released into the wild, 934 on Hawaii island, and 391, half from England, on Maui. But it is not known how many survive or how well they are reproducing. David Zimmerman, writing in Animal Kingdom, says that the most ever seen together is 117 . 
Hawaii's State non-game biologist, David Woodside, guesses 600 on Hawaii and perhaps 200 on Maui. The geese have formidable adversaries. As in Galapagos, introduced animals are major predators on a species that previously had no predators at all: cattle, sheep, goats compete for grazing; pigs, dogs, cats, rats, mongooses (introduced to kill the introduced rats) prey on eggs, young or adults, and the lava terrain is an inhospitable one. Some muchneeded field research is now being planned by Dr Andrew Berger, of the University of Hawaii, and Eugene Kridler, of the US Fish and Wildlife Service in Hawaii. The crucial question is whether the population is now viable or whether it still needs assistance, and if so in what form. A lot of money has gone into the nene programme, and there are 25 other endangered birds in Hawaii, not to mention many more endangered plants. Some think that more money should now go in their direction.

Tigers have never been scientifically recorded in Asia Minor, but in July 1973 a Turkish botanical expedition in south-east Anatolia, not far from the Iraqi border, was told by local hunters in Hakkari and Siirt that tigers existed in the region, and that up to eight animals were taken every Tigers year, the skins being exported usually to Iraq. In an acin Asia Minor count printed in Säugetierkundliche Mitteilungen Turhan Baytop, one of the party, points out that in Turkey (as elsewhere) the name 'tiger' is commonly given to leopards, but he was able to acquire a skin that was indubitably tiger, that of a young male killed in February 1970 near Hakkari. Moreover, furriers in Istanbul confirmed the existence of the tiger population. Up to five years ago, they said, hunters coming from this region had brought them tiger skins for sale, but they had now ceased coming, probably because Iraq was a nearer and more convenient market.

Clive Marsh, one of several scientists who has been working on the Tana River, in Kenya, on the problems of how to protect the two endemic monkeys, the red colobus and the mangabey, is optimistic that a reserve will soon be gazetted which could save them from otherwise certain Reserve extinction. The area proposed for the reserve would inon the clude nearly three-quarters of the remaining animals of Tana River both species, as well as nearly half the remaining forest within their range, and more than half their total habitat. Two reports published in Oryx - one in November 1974 and one in this issue (page 53) - give a clear picture of a very complex situation and the importance of saving a region of such great interest, but where the human population is increasing. All those who have studied the area and the plight of the monkeys agree that conservation can only work if it includes development for tourism, which would provide employment for the local Pokomo people and make them more willing to accept the reserve; without their acceptance it could not survive. Clive Marsh hopes to spend 1975 working with the Kenya Game Department, preparing the ground, demarcating boundaries, clearing roads, 
siting buildings and campsites, and constructing a nature trail. In the process he hopes to be able to interest and enthuse the Game Department staff who will eventually run the reserve.

A very bleak outlook for the survival of the Bactrian deer Cervus elaphus bactrianus in Afghanistan is predicted in a report by Ronald Petocz, Wildlife Consultant there and also our FPS Consultant. After visiting as much of their range - now restricted to two areas on the northern fronBactrian Deer tier with the USSR - as he was allowed or able to visit, in Afghanistan he suggests an optimistic population estimate would be about 120 . The main cause of their decline is the immense influx of human population in the last twelve years and the inevitable habitat destruction to make way for the new settlers' cultivated fields, while pastoral people with domestic animals have settled in the forested areas. Destruction combined with disturbance - people hunting etc-and natural calamities such as high floods and one exceptionally severe winter have reduced the deer to a point where any further natural disaster could bring extinction 'with frightening rapidity'. The only hope of a reasonably safe surviving population is in the forbidden area along the Soviet frontier, from which people have been moved out - a request has been made for further removals. The Governor of the Province is interested and helpful, and a ban on hunting the deer, imposed fifteen years ago, does seem to be enforced. On the Russian side of the frontier the Bactrian deer (called there Bokharan deer) seem to be more numerous - see the report by Dr Bannikov and Dr Zhirnov in Oryx, May 1971 - but here, too, extinction is a real threat. Petocz was fairly certain there could be little interchange between the populations owing to the obstructions (man-made) on the frontier. Some Bactrian deer taken to the former king's hunting reserve in the Ajar valley, Bamiyan province, are reported to be thriving, the numbers having increased from twelve to about sixty. This is now to be declared a wildlife sanctuary administered and guarded by the National Parks sub-department of the Forestry Department.

Conservationists who want to preserve every tree and foresters who are blind to all considerations except economic returns can never hope to agree - or even communicate! Fortunately, extremism is on the wane. In a recent address in Finland, Dr Gerardo Budowski, Director General of Wildlife IUCN, said that today forestry students are demanding and courses that include natural history and wildlife manageForestry ment, hitherto neglected, and 'multiple use' is the new slogan. As a forester himself, Dr Budowski finds it painful to admit that many tropical foresters often cannot even identify the trees they are managing (whereas the local and often illiterate forestry workers can, and also sometimes have much greater ecological knowledge). The trained forester in such cases does not - and cannot - protect the complex forest community he is supposed to manage. The result is friction with the conserva- 
tionists. He outlined four areas in which he believed the two disciplines could usefully work together. First he instanced the planting of 'man-made forests', preferably on non-forested land, designed to ease the pressures on the natural forests by providing for local uses and industries - firewood, building poles, pulp wood, etc. The management of marginal lands was another; immense areas of such land need to be surveyed, mapped, their best uses identified and the decision-making authorities influenced to make the right decisions. A third field for co-operation is the rational selection of national parks; hitherto usually based on hit-and-miss arrangements depending on where there is least demand for the land, this is today a professional job demanding scientific evaluation. Finally, he suggested the administrative field; in developing countries particularly it is vital that national parks, wildlife management and forestry should be working together and not in separate ministries with all the rivalries and lack of communication that that so often entails.

Poaching polar bears is a problem that the specialists in the IUCN Polar Bear Group had to consider at their meeting last December. Rapidly increasing prices for skins are a big incentive, and poachers have been identified from nine countries outside the five that comprise the polar Polar Bears bear's range (Canada, Denmark, Norway, USA and and USSR). The situation has been brought to the notice of Poaching the poachers' governments. In Greenland national parks and reserves are being created that will protect polar bears and allow populations to build up so as to ensure sufficient numbers for Eskimos and other peoples traditionally dependent on them. These are now the only people allowed to hunt polar bears without a licence.

'It is symptomatic that one can get a pretty good book on the natural history of the Galapagos in Bulgarian or German, and dozens in English, but not a single one in Spanish - the native language', writes Peter Kramer, lately Director of the Charles Darwin Research Station in the Spreading the Word in Station's journal Noticias de Galapagos. This is being Galapagos remedied with a series of books and pamphlets on the national park, which covers all the islands except one (Baltra) and the inhabited areas on four, and represents 88 per cent of the land area. All but one are written by Ecuadorians. A Galapagos Information Centre has now been set up in the Central University in Quito to include a library and scientific papers. Another innovation is that four to six university students are invited to the islands every year to work at the station under supervision. For the islanders there is a weekly conservation talk on Radio Galapagos and a regular Bulletin. Introduced predators are still a major threat to the wildlife. Black rats threaten the dark-rumped petrel, which breeds only in Hawaii and Galapagos, with extinction. Goats, which have done immeasurable damage to vegetation on several islands, remain a major problem. However, on Pinta, where three goats introduced in 1957 
multiplied to the point at which 30,000 could be shot in the last four years 'and still leave far too many', the vegetation is recovering well, and the erosion danger on the steep slopes has been averted.

A new reserve for the rare Cape mountain zebra is being established on 10,000 ha. of relatively unspoilt country in the South Western Cape, between Calitsdorp and Oudtshoorn. The area has a rich fauna and flora that includes a very few of the remaining free-living mountain zebras. A New Reserve nucleus herd of 13 animals which is being held temporarily for a on a reserve in Bredasdorp will be reintroduced as soon Rare Zebra as fencing is completed. As the total population of Equus $z$. zebra is believed to be under 170 , mainly in the Mountain Zebra National Park, near Cradock, the new reserve is of considerable importance. With the proper protection from poaching and veld fires that a resident conservation officer will ensure, the zebra population could build up. It is intended also to reintroduce eland, bontebok, black wildebeest and springbok.

On the north coast beaches of Trinidad a 1970 estimate was that 100 per cent of all nesting turtles were killed while nesting. Adult females are killed before being allowed to lay, all shelled eggs found are dug up, and when an adult is killed much of the carcase may be left to rot. These facts Turtle come from a first-class report on the marine turtle situaSlaughter in Trinidad tion in Trinidad and Tobago. Five species breed on these Caribbean islands-green, hawksbill, Pacific ridley, leatherback and loggerhead. The islands have a close season, but it is not enforced, and in any case does not cover the whole nesting season. Turtles are taken in the sea and on land. A case is quoted where hunters killed two turtles, took meat from one and left the other to rot on the beach. There is a profitable trade in turtle meat with hotels, and shells are sold to tourists, the small shells of juveniles fetching the highest prices. The report points out that other Caribbean governments, for example Mexico and Colombia, use armed soldiers to patrol turtle nesting beaches, while Cuba restricts turtle exploitation to registered fishing co-operatives - which then make very sure there is no poaching. The report urges the need immediately to appoint Turtle Protection Officers and the transference of protection duties to the Forest Division's game wardens, who could be assisted by honorary game wardens drawn from amateur naturalists. For the remarkable thing about this very professional report is that this research was initiated and successfully achieved thanks to the Trinidad Field Naturalists' Club, which started collecting information and statistics on marine turtles in 1965. In 1969 their project was incorporated into the research programme of the Biology Department in the University of the West Indies under the direction of Peter Bacon, who wrote the report, but club members continued to do much of the field work. The Club also started the very successful scheme of paying rewards to fishermen for not killing nesting turtles to which FPS contributed with an ORYX 
$100 \%$ Fund grant. This certainly allowed some turtles to lay their eggs and return to the sea. What is more the Club got good publicity because it was done on a popular beach, near a fashionable hotel. And education is clearly the crying need in Trinidad and Tobago, if only to show people that they can have more turtle meat if they allow some turtles to lay their eggs and survive to another year.

In California the increase in sea otters, once almost exterminated there, has seriously disturbed the abalone fisherman. Fishing for these shellfish is important both commercially and for sport, and undoubtedly sea otters take abalone. But research on the sea otters in the Aleutian

Sea Otters Islands shows that a healthy sea otter population is very v.

Fishermen beneficial to the ecosystem. Sea otters effectively control sea urchins which otherwise overgraze the kelp. The kelp in turn is important for the many invertebrates lower in the food chain, which themselves are important food for large animals. So that a reduction in sea otters means, among other things, a reduction in food for harbour seals and bald eagles. The sea otter's importance as a 'keystone' species (one that controls the welfare of many other species) needs further investigation, but at least hasty measures allowing the reduction of sea otters off California should not be rushed. Today the otters are to be found along 110 miles of the coastline, from Monterey Bay to Estero Bay, having been believed extinct off California after about 1911 until they were rediscovered in 1938. But this is still only a fraction of their area before the fur-traders got to work.

A number of attempts to capture small surviving groups of rare animals with immobilising drugs, in order to move them to safety, have foundered through high death rates during capture. Tsessebe Damaliscus lunatus were instanced by Dr Toni Harthoorn, to whom much of the success in Reducing the developing immobilising drugs is due, in a letter to Nature Capture last year. Not all their precautions, he said, including the Death Rate use of a helicopter to reduce the time between first alerting the animal and firing the dart, could stop the deaths, usually highest in calves and gravid females. The cause has now been identified and what looks like a successful treatment developed. These deaths, he says, are not caused by what has been called 'capture myopathy' - exhaustion and overstraining of muscles and vital organs - as had been thought, but mainly by acute and profound acidosis which continues even after the animals have been captured. With zebras even crating them causes acidosis, so that the process continues while they are being transported. Dr Harthoorn and two other South African scientists tried out a therapy to treat this condition on six wild zebra; all survived, while three untreated animals captured with them died within twelve hours from 'capture myopathy'. Dr Harthoorn emphasises that great expertise and knowledge of the animals is needed for successful 
drug-darting. Zebra and wildebeest can be immobilised easily, but oryx, roan and sable need large amounts of very powerful tranquillisers before they can be safely handled. Nyala and kudu are highly nervous and need several tranquillisers simultaneously to calm them. Once in enclosures they can be tranquillised first and immobilised when sedated.

In the search for new African mammals for domestication, particularly for species more suitable than European cattle, eland are usually the favourite candidates. Some recent studies on the Galana River, in Kenya, however, suggest that, at least in the semi-arid areas where the need Oryx is most urgent, beisa oryx could be more suitable. In the for $\quad$ African Wildlife Leadership Foundation's News, Jeffrey

Domestication? Lewis puts forward some tentative results on the work he has been doing there sponsored by the AWLF. Because they need shade in the hottest part of the day, free-ranging eland in hot dry areas feed largely or almost exclusively at night. This is not possible under farm conditions where they are penned in at night, and the animals may not be able to gather enough food in the daylight hours if the heat becomes too great. Eland have an inbuilt mechanism that allows their body temperature to rise, enabling them to withstand great heat, but as the animal's temperature rises its efficiency in utilising food declines, and if it were already going short this would exacerbate the situation. Beisa oryx, on the other hand, graze longer in order to take in the food they require, but they are not deterred by the heat and can graze much poorer vegetation. Studies on both animals sponsored by EAWLS are being continued both on the Galana River and in the Rift Valley, where also experiments in marketing meat from domesticated eland are being tried.

Dam building on some Brazilian rivers has had an unexpected and unwelcome effect on two species of fish, the predatory piranha and the dourado which preys on the piranha and normally keeps its numbers down. New dams on the main rivers have cut off the current and reduced the oxy-

\section{Dams that Benefit the Predators} gen in the water; this affects the dourados which live and spawn in the middle of the river because they need the rapidly moving water with its higher oxygen content. The result is that dourados are dying out, whereas piranhas, which live in the smoother water close to the banks, are increasing. Dr Johan Frisch, President of the Brazilian Association for Wildlife Preservation, São Paulo, reporting this development to the Smithsonian, adds that the piranhas, which used to be found only in the wilder northern and western parts of Brazil, are spreading eastwards, partly due to the new hydroelectric system connecting western and eastern Brazil, and also to the fact that ducks eat piranha eggs and often carry eggs on their feathers and legs to other rivers. An attempt to control the piranha by introducing another predator failed; now an artificial oxygenator is being tried. 
Another dam story comes from the USA. The razorback sucker is a rare fish found in the Colorado and Green Rivers systems. Two years ago it was found that while numbers of adult fish were normal in the Colorado, few of the young were surviving. A quick breeding programme in a A Rare hatchery in Arizona was organised, young were successFish fully raised, and it was planned to release them into the Threatened river when they grew to four inches, a few being held in the hatchery as a broodstock for further rearing. What was puzzling was why the razorback should have failed to breed. One cause, suggested the fish biologists, could be the introduction of non-native sport fish, such as bass, which would feed on the young; another the 'devastating' effect of new dams on the river. Before the river flow was regulated the females deposited their eggs in the shallows at the water's edge, where, with a constant water temperature of $61^{\circ} \mathrm{F}$, the fry would hatch in a few days. But when the dams were opened to increase the flow of water downstream, the river rose and the water temperature dropped so low that the eggs could not survive. Closed dams, on the other hand, meant lower than normal water levels downstream and razorback eggs would be stranded above the water line.

The US Fish and Wildlife Service, after a two-year investigation, has brought to court yet another US firm of fur brokers, who pleaded guilty to trading in ocelot, jaguar, giant otter and margay skins. The skins were brought out of

Brazil, where their export is illegal-this makes them More Fur illegal imports in the USA - in December 1971 and Smugglers January 1972, and shipped to Europe via Canada labelled Caught

'seeds' or 'leathers'. The firm has now had to sign an injunction which will make it very difficult for them to repeat such a transaction, and is also bound now and in future to name any fur firms with whom they have had or will have dealings. The US Department of the Interior means business! At the end of 1974 special agents of the Fish and Wildlife Service seized thousands of eagle and migratory bird feathers, dozens of eagle and migratory bird carcasses, and hundreds of curios made with parts of federally-protected birds. More than 60 individuals, operating independently, were either arrested or issued with summonses for trafficking in eagles and migratory birds. But as always in these cases it is the buyers' demand that is the trouble.

\section{Butterfly Smuggling}

Birds of paradise and the large birdwing butterflies are being smuggled out of Papua - New Guinea despite the Government's determined efforts to stop them. Considerable numbers have been confiscated, and the Minister of Agriculture, $\mathrm{Dr}$ Guise, has said, 'I will do everything in my power to deport these unscrupulous persons who are exploiting the country's birds and butterflies'. But when a pair of butterflies may fetch $\$ 600$ it is not surprising that the smugglers are equally determined. 